The Elsam Saga - Danish Court Rul-ing on Excessive Pricing in Relation to the Delivery of Electricity (ELSAM III)

Bergqvist, Christian

Published in:

SSRN: Social Science Research Network

Publication date:

2016

Citation for published version (APA):

Bergqvist, C. (2016). The Elsam Saga - Danish Court Rul-ing on Excessive Pricing in Relation to the Delivery of Electricity (ELSAM III). SSRN: Social Science Research Network. 


\title{
THE ELSAM SAGA - DANISH COURT RULING ON EXCESSIVE PRICING IN RELATION TO THE DELIVERY OF ELECTRICTY (ELSAM III)
}

\author{
Denmark, electricity, abuse of dominance, article 102, excessive pricing \\ By Christian Bergqvist, Ph.D., Associated Professor, University of Copenhagen, and Laurits \\ Schmidt Christensen, Associate Partner, Attorney-at-Law, Accura Law firm
}

\section{Summary of the case}

In an August 2016 ruling $^{1}$ the Danish Maritime and Commercial High Court $(S \phi-$ \& Handelsretten) confirmed that the Danish energy incumbent DONG Energy A/S ("DONG") had infringed Article 102 and the Danish equivalent by charging excessive prices for the delivery of electricity in 2005-06. The judgment pertained to a 2007 decision by the Danish Competition and Consumer Authority ("DCCA") which had subsequently been challenged by DONG on the basis that DONG was neither dominant nor had acted abusively. In DONG's view it was merely supplying electricity at market prices and in accordance with commitments agreed with the DCCA in 2003. The case is the first of three inter-related abuse of dominance cases pending before the Danish courts regarding the Danish energy incumbent and its alleged abusive pricing of electricity. The judgment was almost instantly appealed. This comes at little surprise as another of the three cases involves claims for compensation now totalling approximately DKK 8 billion (EURO 1.07 billion). In the light of the magnitude of this compensation claim the legal fees and costs of challenging the underlying abuse cases would appear negligible. The August 2016 ruling is therefore only the first round of a legal battle that is expected to continue for the next couple of years. The case offers an interesting insight into how and how not to apply Article 102 to excessive pricing of electricity, as the DCCA 2007 decision sets out a number of principles in relation to the appropriate legal standards, costs and profits which were all reviewed by the court. The judgement and comments to specific extracts from the case follows below.

\section{Background to the case and the road to the Maritime and Commercial High Court}

It is essential to understand that there is not just one case against DONG but in fact four: the DCCA decisions in ELSAM I, ${ }^{2} I^{3}$ and $I I^{4}$ and a compensation claim case based on the ELSAM $I I$ and III decisions. For background information it should be noted that none of these cases involved dominant or abusive behaviour by DONG as such, but rather by the company ELSAM

\footnotetext{
${ }^{1}$ S $\phi$ \& Handelsrettens dom af 30. august 2016 i sag U-1-08 - DONG Energy A/S mod Konkurrencerådet. The ruling includes a full copy of the entire 2007 decision and the subsequent 2008 review by the Competition Appeals Tribunal. In this paper references to the 2007 decision are therefore made to the relevant page of the 2016 court ruling. A copy of the 504 page ruling can be found at http://domstol.fe1.tangora.com/Domsoversigt.16692/U-1-08,1.-del,-side-1-250.1773.aspx

${ }^{2}$ Analyse af Elsam A/S og Energi E2 A/S adfard på markederne for elspot i 2000 og 2001 (ELSAM I). Decision from the Competition Council of 26 March 2003.

${ }^{3}$ Elsam A/S misbrug af dominerende stilling i form af høje elpriser (ELSAM II). Decision from the Competition Council of 30 November 2005.

${ }^{4}$ Elsams elpriser i 2005 og 2006 (ELSAM III). Decision of the Competition Council of 20 June 2007.
} 
which DONG acquired in $2005 .^{5}$ The ELSAM I investigation itself did not result in an actual infringement decision but was closed subject to commitments. The ELSAM I commitments was, however, later revoked by the DCCA on the grounds that the commitments had not been complied with. DONG disputed this and later argued, in vain, that it had merely acted in accordance with these commitments and therefore had not acted abusively. The ELSAM II (2005) and ELSAM III (2007) investigations on the other hand were 'finalised' into actual infringing decisions that DONG had charged excessive prices during the $2^{\text {nd }}$ half of 2003 and 2004 (ELSAM II) and in 2005-2006 (ELSAM III). The latter decision was, however, partially overturned on appeal to the Competition Appeals Tribunal as regards the $2^{\text {nd }}$ half of 2006 thereby limiting the finding of the abuse to a total of 3 years rather than a $3 \frac{1}{2}$ years period. DONG challenged both decisions before the judiciary. In parallel, approximately 1100 companies/electricity customers claiming to have suffered losses filed a law suit for compensation for overcharges. ${ }^{6}$ As mentioned, ELSAM had in the meantime been acquired by the incumbent DONG.

\section{The DCCA 2007 decision on abuse and excessive pricing}

The recent August 2016 ruling confirms that the DCCA correctly found an infringement of Article 102 and the Danish equivalent by its decision of June 2007 (ELSAM III). The DCCA found DONG to be dominant in the market for the delivery of electricity in the Western part of Denmark. $^{7}$ The DCCA based its findings not only on DONG's high market share but also on other facts such as the flexibility of DONG's production portfolio, its excess generation capacity, and the existence of substantial access barriers as well as market transparency. ${ }^{8}$ The DCCA noted that in many instances DONG would be the only producer with excess capacity and hence the ability to produce to meet market demands. As Western Denmark is linked to other countries including Norway and Sweden by direct interconnectors the dominant position was partly mitigated during certain hours by imports. However, the interconnectors were often congested making the dominant position not only reoccurring but also one which was easy to predict for DONG. Further, through strategic bidding it was allegedly possible for DONG to influence interconnector capacity and congestion. ${ }^{9}$ This restrained non-domestic producers' abilities to mitigate DONG's market power through imports. Despite a relatively successful market opening in 2000 and Denmark's adherence to the Nordic electricity pool platform (Nord Pool), the Danish electricity market was still in its infancy in 2005 and 2006, and DONG was in a position to exploit flaws in the market/infrastructure design through strategic bidding. This strategic bidding was carried out in accordance with a written production optimization plan which was later uncovered during a dawn raid. ${ }^{10}$

\footnotetext{
${ }^{5}$ DONG A/S acquired ELSAM in 2005. This acquisition was reviewed and approved by the Commission in COMP/M.3868-DONG/Elsam/Energi E2. Today DONG A/S is a publicly listed company.

${ }^{6}$ Case U-10/07 - Tetra Pak Inventing A/S m. fl. mod DONG Generation A/S og DONG Energy Power A/S.

${ }^{7}$ For historical and geographical reasons are Denmark divided into two different electricity zones separated by the Great Belt and unlinked until 2010.

${ }^{8}$ S $\phi$ \& Handelsrettens dom af 30. august 2016 i sag U-1-08 - DONG Energy A/S mod Konkurrencerådet, pp. 38-57. While DONG's 2005-2006 market share formally was below 50 per cent, the DCA noted that DONG's ability to exercise market power would reflect a 79 per cent market share.

${ }^{9}$ S $\phi$ \& Handelsrettens dom af 30. august 2016 i sag U-1-08 - DONG Energy A/S mod Konkurrencerådet, p. 56.

${ }^{10}$ See ELSAM II, recital 106 and 139 and 237
} 


\section{The relevant market was defined as the delivery of electricity in Western Denmark.}

In reaching its finding of dominance the DCCA defined a product market for wholesale of electricity, i.e. the physical delivery of electricity to the market, ${ }^{11}$ in which DONG was active in competition with other but smaller producers. Imports were available at certain times but as detailed above imports and the competitive pressure from imports were reduced by infrastructure congestion and limited transmission capacity. The 'wholesale of electricity' market definition follows from EU precedents and was essentially the only issue not disputed by DONG during the subsequent appeals. Adjacent to the main wholesale of electricity market were a number of markets for e.g. balancing power and for financial products used to off-set fluctuations in the market price. In the early years of market opening the risk of fluctuation of the market price was a considerable concern for retailers (i.e. intermediators between wholesalers and end-users). This had created a demand for such financial products. These financial products were sold by DONG essentially offering insurance against the price fluctuations caused by DONG' exercise of market power. While the financial product market was not directly at issue in neither ELSAM III nor in ELSAM II, it is of importance for the compensation cases. Geographically, the wholesale of electricity product market was confined to Western Denmark. ${ }^{12}$

\section{The DCCA' finding of excessive pricing}

Following the finding of a dominant position under Article 102 and the Danish equivalent the DCCA moved on to assess if an abuse of the position had been committed. Reference was made to the case United Brands ${ }^{13}$ that established that a price may be deemed excessive if the:

a) profit is excessive - which, requires a comparison of price, costs and risks, and

b) price is excessive - which requires a comparison with competing products and services and what is charged in other relevant markets.

In its assessment of the first part of the test, the DCCA calculated the relevant costs, including variable and fix costs, based on the audited annual accounts, ${ }^{14}$ and then 'distributed' these costs on a per hour basis. Moreover, the DCCA added a perceived fair rate of return on investments (fixed at 10 percent). ${ }^{15}$ In respect of the second part of the test, the DCCA did not carry out a comparison of the actual prices charged against prices in other zones under Nord Pool e.g. Norway and Sweden, but carried out its assessment on the basis of a price which in itself could be considered unfair - in the light of the prices charged by DONG during the so-called noncritical hours (see below). For the purpose of further determining this price element, a 'price variation supplement' (to balance the hours where the market price did not cover DONG's

\footnotetext{
${ }^{11} S \phi \&$ Handelsrettens dom af 30. august 2016 i sag U-1-08 - DONG Energy A/S mod Konkurrencerådet, pp. 27-29.

${ }^{12}$ S $\phi$ \& Handelsrettens dom af 30. august 2016 i sag U-1-08 - DONG Energy A/S mod Konkurrencerådet, pp. 29-36.

${ }^{13}$ Case C 27/76 - United Brands, ECR 1978, p. 207 recital 248. It is unclear whether the tests are alternatives or a two parts test as detailed by Jonathan Faull and Ali Nikpay, The EC Law of Competition Oxford, $3^{\text {rd }}$ edition 2014, p. 514. However, the DCCA applied it as a two parts test. Conversely, DONG had argued that it could not be abusive to charge prices corresponding to the economic value of goods as expressed by the customer' willingness to pay. The DCCA noted that an acceptance of this argument would render the whole concept of excessive pricing meaningless. See $S \varnothing$ \& Handelsrettens dom af 30. august 2016 i sag U-1-08 - DONG Energy A/S mod Konkurrencerådet, p. 58.

${ }^{14}$ Before the court it was submitted that the applied costs actually exceeded those extractable from the audited accounts by 22 to 37 per cent. See $S \phi$ \& Handelsrettens dom af 30. august 2016 i sag U-1-08-DONG Energy A/S mod Konkurrencerådet, p. 443.

${ }^{15}$ Sф \& Handelsrettens dom af 30. august 2016 i sag U-1-08 - DONG Energy A/S mod Konkurrencerådet, pp. 59-69.
} 
$\operatorname{costs}^{16}$ ) as well as a 'CO2 quota supplement' were included in the calculation. ${ }^{17}$ The CO2 quota supplement was included in the calculation to reflect the fact that the $\mathrm{CO} 2$ quota - despite having being allotted to DONG for free - represented an asset and consequently warranted a rate of return. Accordingly, in its assessment of the second part of the test, these two 'supplements' were added to the calculation of the costs for the purpose of determining if the prices charged by DONG exceeded the relevant cost benchmark. Only for the hours where the cost benchmark was exceeded - referred to as the "critical hours" - did the DCCA find an abuse. ${ }^{18}$ For the full years 2005 and 2006 the 'critical hours' were in total 1,484 hours or approximately $8.5 \%$ of total time. ${ }^{19}$

To firm up its finding of abuse the DCCA carried out five additional tests. These included comparing prices in the critical hours with prices in the non-critical hours, and testing if the inflated price and marginal revenue in the critical hours could be seen as necessary to secure an overall acceptable rate of return. ${ }^{20}$ As all the additional tests confirmed a finding of excessive pricing, the DCCA found an infringement of Article 102 and the Danish equivalent. Moreover, the DCCA calculated a direct consumer loss amounting to between DKK 111 million (EURO 15 million) and DKK 783 million (EURO 105 million) depending on the inclusion of the CO2 quota supplement in the calculations.

\section{Review by the Competition Appeals Tribunal and subsequently by the courts}

DONG appealed the 2007 decision (ELSAM III) to the Danish Competition Appeals Tribunal (Konkurrenceankencevnet), an administrative appeals body that essentially upheld the decision ${ }^{21}$ and subsequently to the Maritime and Commercial High Court ( $\phi \phi$ - og Handelsretten). The Danish Maritime and Commercial High Court has a special status in relation to the review of decisions from the DCCA as well as generally in matters involving competition law. Moreover, the appeal of ELSAM II was already pending before the Maritime and Commercial High Court. In addition, approximately 1100 customers of DONG claiming to have suffered losses from the abuse had initiated a compensation claim law suit based on ELSAM III and ELSAM II before the same court. These compensation claims were originally calculated at DKK 4.6 billion (EURO 617 million) but with accumulated interest they summed approximately DKK 8 billion (EURO 1.07 billion) in 2016. In addition to their direct losses caused by the overpricing the customers included two kinds of indirect losses in the calculation of their claims. These included first and foremost the costs of the financial products necessary to off-set the price fluctuation caused by DONG's behaviour and, secondly, the costs of having paid generally inflated market prices to other producers than DONG. As the sum of the total claims do not represent actual gains for

\footnotetext{
${ }^{16}$ A large number of the involved power plants combined the production of heating and electricity making it impossible to shut down the plant when the electricity price did not cover the direct cost. Hence, a supplement had to be included to compensate for this - the price variation supplement. See S $\phi$ \& Handelsrettens dom af 30 . august 2016 i sag U-1-08 - DONG Energy A/S mod Konkurrencerådet, pp. 70-71.

${ }^{17}$ S $\phi$ \& Handelsrettens dom af 30. august 2016 i sag U-1-08 - DONG Energy A/S mod Konkurrencerådet, pp. 70-76.

${ }^{18}$ In practice it was insufficient for a finding of abuse that the price exceeded the benchmark in a single hour as the DCCA decided to apply the test against a combination of three and ten hours' average prices to produce more valid results. See $S \phi$ \& Handelsrettens dom af 30. august 2016 i sag U-1-08 - DONG Energy A/S mod Konkurrencerådet, p. 59.

${ }^{19}$ S $\phi$ \& Handelsrettens dom af 30. august 2016 i sag U-1-08 - DONG Energy A/S mod Konkurrencerådet, p. 80. In light of the structure of the applied test -using conservative calculations - it was in principle kept open if abusive pricing also could have been found in additional hours.

${ }^{20}$ S $\varnothing$ \& Handelsrettens dom af 30. august 2016 i sag U-1-08 - DONG Energy A/S mod Konkurrencerådet, pp. 76-82.

${ }^{21}$ DONG Energy A/S. Decision of the Competition Appeals Tribunal of 3 March 2008.
} 
DONG, an important issue in the forthcoming compensation case will therefore involve deciding if such losses are compensated under Danish law.

\section{The case before the Maritime and Commercial High Court}

Before the Maritime and Commercial High Court an agreement was entered into to stay the review of ELSAM II and to allow the ELSAM III decision to serve as test case. Moreover, also the compensation claim case was put on hold pending the outcome of the review of ELSAM III ${ }^{22}$ and in principle also ELSAM II as the claims rest upon both decisions. Conversely, the parties did not agree on whether a reference for a preliminary hearing to the European Court of Justice $^{23}$ on the concept of excessive pricing was required. DONG requested this but the Maritime and Commercial High Court decided not to make reference.

\section{DONG's submissions and DCCA's reply before the Maritime and Commercial High Court}

As explained above, the DCCA had applied a test that involved calculating DONG's hourly production costs with the addition of various cost supplements. The supplements were included to reflect general economic theory on how an undertaking would price its products. However, this approach was rejected by a report on economic issues ${ }^{24}$ prepared by court-appointed economical experts. The court-appointed expects also found that the applied 10 per cent rate of return on investment was too low. Danish companies had on average obtained a rate of return of 19.6 per cent during $2005-2006 .^{25}$

Against this background DONG asserted in its defence - in addition to arguing not being dominant and that the mentioned 2003 commitments 'permitted' its pricing behaviour ${ }^{26}$ - that: ${ }^{27}$

1) The applied rate of return of 10 per cent was too low as the relevant rate of return in the relevant period was 19.6 per cent.

2) Rather than relying on the historical costs set out in the annual accounts, opportunity cost or as a proxy 'replacement costs' had to be used for the purpose of establishing the relevant benchmark. Opportunity costs better represented how undertakings view costs and were in general significantly higher than the annual accounts-based cost figures. ${ }^{28}$

3) The value of the $\mathrm{CO} 2$ quota represented a relevant cost item - despite having been allotted at no costs to DONG - as the appropriate concept of costs should also include 'sacrifice costs' as DONG could otherwise have opted to sell the quotas.

4) The decision was based on a number of errors and miscalculations e.g. in relation to the price variation supplement. Moreover, the hour-based approach was flawed and did not take into consideration the need to adopt a longer perspective on total costs recovery. In

\footnotetext{
${ }^{22}$ Some minor processual questions in the compensation case were advanced, eventually decided by the Supreme Court, on the legal value and use of an economic expert opinion of the suffered loss.

${ }^{23} S \phi \&$ Handelsretten kendelse af 24. april 2009 - DONG Energy mod Konkurrencerådet.

${ }^{24} \mathrm{~S} \phi$ \& Handelsrettens dom af 30. august 2016 i sag U-1-08 - DONG Energy A/S mod Konkurrencerådet, pp. 154, 175,176 and 193-195.

${ }^{25}$ S $\phi$ \& Handelsrettens dom af 30. august 2016 i sag U-1-08 - DONG Energy A/S mod Konkurrencerådet, p. 147148.

${ }^{26}$ For further on the agreement see $S \phi \&$ Handelsrettens dom af 30. august 2016 i sag U-1-08 - DONG Energy A/S mod Konkurrencerådet, pp. 370-385 (DONG's submissions) and pp. 492-496 (DCCA's submission).

${ }^{27}$ S $\phi$ \& Handelsrettens dom af 30. august 2016 i sag U-1-08 - DONG Energy A/S mod Konkurrencerådet, p. 196-210 followed by further detailing of each of the alleged "problems".

${ }^{28}$ See $S \phi \&$ Handelsrettens dom af 30. august 2016 i sag U-1-08 - DONG Energy A/S mod Konkurrencerådet, pp. 302-313.
} 
fact, the DCCA's own calculations showed costs exceeding the charged prices which arguably made it difficult to conclude that these were excessive and abusive.

5) In light of this the prices charged did not even cover DONG's costs - neither DONG's actual costs nor the (artificially low) costs calculated by the DCCA. Moreover, the prices in Western Denmark had in general been in line with the prices in Eastern Denmark and Germany.

DONG's strategy was basically to argue that the 2007 decision suffered from so many errors and misconceptions that the finding of abuse was not supported by sufficient evidence and therefore had to be overturned. Furthermore, DONG argued that cases such as United Brands and Helsingborg Havn ${ }^{29}$ should be interpreted to allow for the inclusion of non-economic factors in the assessment of the value of a product or a service. ${ }^{30}$ In DONG's view the assessment should also include different demand-related items as well as the price in other markets. In DONG's view, it was inadequate to base a finding of abuse on the fact that prices had exceeded costs. ${ }^{31}$

In response the DCCA essentially submitted that while there could be (minor) miscalculations and misconceptions in the calculations made e.g. the inclusion of supplements for price variation and $\mathrm{CO} 2$ quotas, ${ }^{32}$ none of these raised doubt as to the finding of abuse. The applied tests were 'very conservative' as they resulted in costs which on average exceeded DONG's actual costs with more than 130 per cent. ${ }^{33}$ In the DCCA's view the tests were therefore clearly adequate to assess and identify an excessive pricing abuse. Moreover, the calculations on the revenue side did not include other sources of income e.g. revenue from the supply of balancing power to the system operator and from the supply of heating. ${ }^{34}$ Moreover, DONG would in practice not have been in a position to sell the $\mathrm{CO} 2$ quotas which therefore in principle represented a value of zero. ${ }^{35}$ Finally, the DCCA argued that it should be allowed an extended margin of appreciation in this type of cases which in practice would mean limiting the review powers of the courts. ${ }^{36}$

\section{The Maritime and Commercial High Court's ruling}

Following a lengthy court procedure including what could be seen as delaying tactics by DONG, e.g. by requesting an unusual large number of court days, the Maritime and Commercial High Court delivered its ruling in August 2016. The court upheld the DCCA's finding of abuse of dominant position, however, rejected the underlying calculations and estimations of costs and profits. ${ }^{37}$ No clear reasoning was provided except for general references

\footnotetext{
${ }^{29}$ COMP/A.36.568/D3 - Helsingborg Havn.

${ }^{30}$ S $\phi$ \& Handelsrettens dom af 30. august 2016 i sag U-1-08 - DONG Energy A/S mod Konkurrencerådet, pp. 223224.

${ }^{31}$ S $\varnothing$ \& Handelsrettens dom af 30. august 2016 i sag U-1-08 - DONG Energy A/S mod Konkurrencerådet, p. 226.

${ }^{32}$ Sø \& Handelsrettens dom af 30. august 2016 i sag U-1-08 - DONG Energy A/S mod Konkurrencerådet, pp. 428429 .

${ }^{33}$ S $\phi$ \& Handelsrettens dom af 30. august 2016 i sag U-1-08 - DONG Energy A/S mod Konkurrencerådet, p. 409.

${ }^{34}$ Sф \& Handelsrettens dom af 30. august 2016 i sag U-1-08 - DONG Energy A/S mod Konkurrencerådet, pp. 445446.

${ }^{35}$ Sф \& Handelsrettens dom af 30. august 2016 i sag U-1-08 - DONG Energy A/S mod Konkurrencerådet, p. 471.

${ }^{36}$ S $\phi$ \& Handelsrettens dom af 30. august 2016 i sag U-1-08 - DONG Energy A/S mod Konkurrencerådet, pp. 411412.

${ }^{37}$ S $\phi$ \& Handelsrettens dom af 30. august 2016 i sag U-1-08 - DONG Energy A/S mod Konkurrencerådet, pp. 501503.
} 
to the case documentation. It would appear that the court may have taken comfort in the original calculations as being 'conservative' in the light of the different supplements and therefore underestimating DONG' costs. Accordingly, the court upheld the finding of an infringement of Article 102 and the Danish equivalent during the period from 2005 to the $1^{\text {st }}$ half of 2006. Remarkably, the DCCA's argument that the review powers of the courts are limited was rejected. Decisions from the DCCA are subject to full review by the courts also when it comes to calculations and valuations - save for in very specific instances where an administrative body is better positioned to carry out the balancing of different objectives. Under applicable feeshifting rules DONG was ordered to pay the DCCA's costs set at approximately DKK 4.6 million (EURO 600.000).

\section{What to extract from the ruling?}

As noted above, the ruling has already been appealed. This makes it premature to extract clear and final principles from the case. Moreover, while upholding the finding of an abuse of dominance many of the calculations made by the DCCA were rejected which makes it even more difficult to draw any final lessons from the ruling. It would appear that the 2007 decision is based on a reading of Article 102 that makes it abusive to charge prices exceeding costs including a standard profit - at least in a market with limited risk and highly predictable consumer demand. This would arguably correspond to a restrictive reading of Article 102. It appears that the Maritime and Commercial High Court's ruling sets aside this restrictive reading by defining excessive pricing as requiring excessive profit in the light of costs and risks. On the matter of how to define excessive the court offers no detailed guidance. Moreover, in calculating the costs the DCCA had taken a position on a number of issues that formed part of the subsequent case e.g. whether assets should be valued at the audited value or at replacement costs. The former approach is probably the correct reading of EU practice but the latter is not without merits from a commercial perspective. ${ }^{38}$ This is an additional issue where the ruling does not offer guidance as both approaches would appear to be found in the 2007 decision and the DCCA's subsequent submissions. By contrast the Maritime and Commercial High Court was very clear and specific in relation to its powers to review the DCCA's decisions. There are no limitations to the court's power to review DCCA decisions except in some very specific circumstances. Presumably, the DCCA will seek to challenge this part of the ruling during the forthcoming appeals case. By contrast, it is expectable that DONG may introduce as an argument that it would appear 'illogical' to set aside essentially all of the original calculations and at the same time upholding a finding of abuse based on this:

\footnotetext{
${ }^{38}$ For a case pertaining to this question, see COMP/A.36.568/D3 - Scandlines Sverige AB v Port of Helsingborg, recitals 83 and 109, which was based on historical cost extracted from the audited accounts.
} 